Scholedge International Journal of Multidisciplinary \& Allied Studies ISSN 2394-336X, Vol.04, Issue 02 (2017) Pg 10-15.

DOI: $\underline{\text { 10.19085/journal.sijmas040201 }}$
Published by: Scholedge R\&D Center www.theSCHOLEDGE.org

Email: editorial@thescholedge.org

CPublisher

\title{
IMMIGRANT EXPERIENCE AND SELF-IDENTITY IN BHARATI MUKHERJEE'S JASMINE: A STUDY
}

\author{
G. Sankar \\ PhD Research Scholar in English, National College (Autonomous), Tiruchirappalli-620 001, India. \\ Dr. R. Soundararajan \\ Associate Professor \& Research Guide Department of English, National College (Autonomous), \\ Tiruchirappalli-620 001, India.
}

\begin{abstract}
This Research Paper is an aim to attempt the traumatic experiences and cultural perplexity of the first and second generation immigrants and which explores the depth analysis of women consciousness, self discovery and their immigrant experiences among the male dominated society in Bharati Mukherjee's Jasmine (1989), which set in the present about a young Indian woman Jasmine in the United States who, trying to adapt to the American way of life in order to be able to survive, changes identities several times. The state of exile, a sense of loss, the pain of separation and disorientation makes Jasmine as Immigrant personality in a quest for identity in an alien land. Jasmine, the protagonist of this novel, undergoes several transformations during her journey of life in America, from Jyoti to Jasmine to Jane, and often experiences a deep sense of estrangement resulting in a fluid state of identity. This Research paper finds out the research hypothesis, how the protagonist jasmine try to assimilate herself into foreign culture where she gains new independent individual identity.
\end{abstract}

KEYWORDS: Women consciousness, Self discovery, Immigrant experiences, Separation, Disorientation

\section{Introduction}

Mukherjee is a diasporic writer and her main focus is to bring out the conflict and the suffering of the women who have settled abroad. Her novels are women centered, though she uses a large number of male characters in order to portray the world of her female protagonist. Mukherjee's women characters are people from the periphery of society who chose to spend their lives in an alien country. Mukherjee's Jasmine explores the socio-political issues that determine the position on American identity through the migration narrative of its title character. Several wellknown scholars find out what they interpret as Mukherjee's celebration of assimilation and adoption of Western feminist values problematic, arguing that she idealizes the United States at the expense of her homeland. Moreover, these critics contend that Jasmine's development relies on American and European models of personal success, thereby reinforcing notions of the ever-victimized "third world" woman rescued by liberal Western values.

Bharati Mukherjee, an Indian born Canadian/American novelist, has made a deep impression on the literary canvass. Her novels honestly depict the issues of her own cultural location in West Bengal in India. They were displaced and alienated from her land of origin to USA where she is "simultaneously invisible" as writer and "overexposed" as a racial minority and her final re-location (assimilation) to USA as naturalized citizens. She is the writer of The Tiger's Daughter (1971), Wife (1975), Jasmine (1989), The Holder of the World (1993), Leave it to me (1997), Desirable Daughters (2002), The Tree Pride(2004),Miss New India(2011).

Jasmine, the title character and narrator of Bharati Mukherjee's Jasmine, was born approximately 1965 in a rural Indian village called Hasnpur. She tells her story as a twenty-four-year-old pregnant widow, living in Iowa with her crippled lover, Bud Ripplemeyer. It takes two months in Iowa to relate the most recently developing events. But during that time, Jasmine also relates biographical events that span the distance between her Punjabi birth and her 
American adult life. These past biographical events inform the action set inIowa. Her odyssey encompasses five distinct settings, two murders, at least one rape, a maiming, a suicide, and three love affairs. Throughout the course of the novel, the title character's identity, along with her name, changes and changes again: from Jyoti to Jasmine to Jazzy to Jassy to Jase to Jane. In chronological order, Jasmine moves from Hasnpur, Punjab, to Fowlers Key, Florida (near Tampa), to Flushing, New York, to Manhattan, to Baden, Iowa, and finally is off to California as the novel ends.

\section{The Story of Jasmine}

"Jasmine" is an account of adaptation and not a defeat. It is the story of a Punjabi rural girl, Jyothi. Prakash, an energetic and enthusiastic young man entering Jyothiees life as her husband. When Prakash prepares to go to America, she says, "I'll go with you and if you leave me, I will jump into a well". A woman has to accept, the path of her husband, Renamed as Jasmine, joyously sharing the ambition of her husband, she looks forward going to America, a land of opportunities even this dream gets shattered by the murder of Prakash on the eve of his departure. She decides to go America and fulfill Prakash"s mission and perform "Sati". Having learned to "Walk and Talk" like an American, she grabs every opportunity to become American. Jasmine becomes Jase. At the end she kills Sukhawinder, the Khalsa lion who killed Prakash. After that she goes to Iowa assuming a new name "Jase". The manifold facets or roles played by Jasmine as Jase and Jane assault the power in woman. This power can be equal to Sakthi which is command over quality that destroys and fights against all evils. Jasmine has broken away from the shackles of caste, gender and family. She has learnt to live not for her husband or for her children but herself. Jasmine is a survivor, a fighter and an adaptor. She figures against Unfavorable circumstances, comes out a winner and carves out a new life in an alien country.

In Jasmine is based on Muckherjee's short story by the same name. Jasmine moves from maidenhood to marriage, to rape, to caregiver. The young age girl Jyoti becomes Jasmine and when her young husband dies due to a terrorist bombast she decides to go America with his clothes, to make a final offering at alter of his dreams. Landing in America as an illegal immigrant she becomes rape and her Indians rebels against this violation she murders the first jasmine moves from one family to another, builds other relationships, acquires the names, finds a shared bond with a Vietnamese refugee and finally leaves, she loves-choosing between 'Indian' duty and the 'Western' pursuit of happiness.

Jasmine undergoes her next transformation from a dutiful traditional Indian wife Jasmine to Jase when she meets the intellectual Taylor and then moves on to become Bud"s Jane. It seems likely that as Jasmine leaves for California with Taylor and Duff, her identity continues to transform. The author depicts this transformation and transition as a positive and an optimistic journey. Jasmine creates a new world consisting of new ideas and values, constantly unmasking her past to establish a new cultural identity by incorporating new desires, skills, and habits. This transition is defined not only in the changes in her attitude, but more significantly in her relationship with men.

\section{Research Methodology}

This novel is the celebration of the American freedom to develop an individual identity, a freedom categorized by both pain and excitement. Most of her writings created an Indian microcosm in US; an Indian environment in a foreign land which is vibrant with Indian food, languages, dress, traditions and customs. One could say that her works reflect the women's plight in the transition. Mukherjee is not interested in dismantling the term "American" by engaging specifically with the demands Jasmine makes on mainstream perceptions of immigrant and American identities. While Mukherjee perhaps does not dismantle the term by stripping American identity of its power and privilege, she does challenge exclusivity and abuses.

Rather than reading Jasmine's character solely as representative of a "third world" woman in the West, it is better to see her as a protagonist whose narrative involves translating a postcolonial Indian female subject-position into the context of immigrant America. As such, she exhibits the potential to change what it means to be "American," and the identity she negotiates is as much a political stance towards ethnic American identification as it is a commentary on the world both Jasmine and her author left behind.

Moreover, it is apparent that this novel cannot be interpreted without making use of the many examples of personal prose written by Mukherjee in which she explores issues of history, identity, culture, gender, and immigration, 
particularly in regard to her work as a writer. Mukherjee's non-fiction reveals many of the attitudes towards Indian and North American cultures that shape Jasmine's development as a postcolonial, immigrant heroine.

Jasmine's narrative is set against the violent historical backdrop of post-Independence, post-partition India: her family comes to settle in their village after the events of 1947 make them outsiders in their ancestral city of Lahore. Although Mukherjee herself is from Bengal, one of the two Indian states actually partitioned, she does not address the split of Bengal in Jasmine. Instead, she displaces this trauma onto Jasmine's Punjabi family. Indeed; recent scholarship about Partition highlights 1947 as a traumatic moment in India's history. In the opening pages of The Other Side of Silence: Voices from the Partition of India, Urvashi Batavia notes that an estimated one million people died from violence, malnutrition, and disease; twelve million people were displaced; acts of "sexual savagery" were committed against approximately 75,000 .

Women thought to have been kidnapped and raped; and thousands of families were divided, losing their loved ones as well as all of their land and possessions. In her collection of interviews with survivors of Partition, Batavia records the human tragedy of an experience widely perceived as a mostly geo-political event. In a more recent study of Partition's effects on Indian cinema, Bashkir Starker also utilizes theories of memory and Trauma to construct " $a$ hermeneutic of mourning" that is particularly relevant in regard to the postcolonial experience.

For Jasmine's family, an acute sense of loss and displacement defines the post-partition, Post-colonial condition. They were forced violently from their comfortable, upper-middle class lifestyle in Lahore - where they had previously owned land and shops, lived in a sprawling home, and were respected for their family name - and forced into a village of flaky mud huts Jasmine narrates how this loss of home, homeland, and status plagues her family:

Marajo, my mother, couldn't forget the Partition Riots. Muslim sacked

Our house, Neighbors' servants tugged off earrings and bangle defiled

Grottoes sobered my grandfather's horse. Life shouldn't have turned out.

That way! I've never been to Lahore, but the loss survives in the instant

Replay of my family story: forever Lahore smokes, forever my parents

Flee. (41)

The trauma of this departure force Jasmine's parents into an exile that makes her mother distrustful and pessimistic, and that her father in particular never comes to accept. Jasmine describes his perpetual attachment to Lahore in the karats he continued to wear, the Pakistani radio broadcasts he listened to, and his disgust for anything not related to Lahore including the mangoes, women, music, and Punjabi dialect of the Indian side of the partition. In the next generation, this trauma replays itself - more and more violently each time- throughout Jasmine's life in India.

However, she continues, "Lacking a country, avoiding all the messiness of rebirth as an Immigrant eventually harms even the finest sensibility" (29). Although her words have given their context in a review aimed at a new direction for minority American literatures - lack the empathy we might expect in a discussion of trauma, they resound in interesting ways with Cathy Carat's work in this area.

She writes that "the traumatic event is not assimilated or experienced fully at the time, but only in its repeated possession of the one who experiences it. To be traumatized is precisely to be possessed by an image or event". Furthermore, she writes that the traumatized "become themselves the symptom of a history that they cannot entirely possess" (5). Haunted by his imagined, Jasmine's father clearly exhibits the symptoms of exile-as-trauma, then Mukherjee argues that by embracing "duality" we might "learn how to be two things simultaneously; to be the dispossessed as well as the dispossessor," thereby working through this exile-as-trauma.

\section{Results and Discussions}

Jasmine's words at the end of the description of her father illustrate this attitude towards such dispossession: "He will never see Lahore again and I never have. Only a fool would let it rule his life" (43). In her willingness to sever any imaginative attachment to her father's homeland, jasmine avoids what Mukherjee describes as the "mordant bite" of exile and instead embraces the messy potential for rebirth as an immigrant when she arrives in the U.S. 
She refuses to believe the astrologer's argument that one is helpless against fate. Jasmine, which at that time is still known as Jota, trips and falls as she runs away, is cutting her forehead when it hits the floor and her sister's shriek when they see her:

"Now your face is scarred for life! How will the family ever find you a

Husband?" (4-5).

"To Jasmine, however, this scar is a "third eye"; rather than submit to the will of fate, she prefers to define her own life. She interprets and resists the implications of the astrologer's pronouncement, refusing to believe that she "was nothing, a speck in the solar system...helpless, doomed" (3-4).

Although Mukherjee does not return to this narrative thread for following upcoming paragraphs, she foregrounds Jasmine's new life in Iowa as the novel's central plot, weaving in the stories of her upbringing, brief marriage, and migration to America, the flashbacks determine how we come to understand "Jane," Iowa's version of the girl from Hanaper. In narrating her birth, Jasmine continues to reveal the burden associated with daughters in her community:

If I had been a boy, my birth in a bountiful year would have marked me as lucky, a child with a special destiny to fulfill. But daughters were curses. A daughter had to be married off before she could enter heaven, and Dowries beggared families for generations. Gods with infinite memories visited girl children on women who needed to be punished for sins Committed in other incarnation. My mother's past must have been heavy with wrongs. I was the fifth Daughter, the seventh of nine children. When the midwife carried me out, my sisters tell me, I had a rubyred Choker of a bruise around my throat and sapphire fingerprints on my collarbone. (39-40)

A daughter's birth is never celebrated or related to the luck of bounty, instead, from the Moment she enters the world, the question of her dowry preoccupies her parents. Mothers who have daughters are doubly cursed: not only were they once unwelcome daughters themselves, but they are also paying for sins from previous lives with each girl child. These attitudes characterize the society into which Jasmine is born, and these beliefs determine how she comes to see herself. From the moment she is born, Jasmine is marked by a will to survive that challenges expectations and possibly fate and foreshadows the events that drive her narrative.

While Mukherjee's representation of Jasmine's early life might seem to suggest that Jasmine's India is stunted by its blind commitment to tradition, which justifiably bothers critics, it is better to see these moments within the critical context of the massive trauma of Partition. Mukherjee is not criticizing her homeland, but exploring the social and cultural impact of this moment on families like Jasmine's, particularly as it pertains to attitudes towards women.

In Jasmine, Mukherjee authors a character defined by her exceptionality and defiance of expectations. While she performs domestic female tasks like boiling milk and haggling prices down at the market with notable skill, she also excels at school. She displays enough promise to be allowed six years of schooling - "three years longer than her sisters," who were married off by a cousin who taught them that men prefer village girls with "no minds of their own". Her mother complains that God is "cruel to waste brains on a girl," but Jasmine's intellectual potential earns admiration from the village teacher, who lobbies for her to be allowed to continue her education and pursue a career.

Jasmine's willingness and ability to go against her grandmother's wishes complicate perceptions of culture and gender roles in Jasmine as stable or fixed. In these scenes, Mukherjee deals with what she more explicitly addresses in several of her non-fiction works. Although her upbringing was quite different from her protagonist's, Mukherjee was born into a wealthy, upper-caste, Hindu family in India's Bengal province, she consistently grapples with similar issues of flexibility, both cultural and political, in determining her own identity. In "Beyond Multiculturalism: Surviving the Nineties," Mukherjee writes:

When I was growing up in Calcutta in the fifties, I heard no talk of "Identity crisis" communal or individual, the concept itself - of a Person not knowing who she or he was - was unimaginable in a hierarchical, classification-obsessed society. One's identity was absolutely fixed, derived from religion, caste, patrimony, and mother tongue. An Indian's last name was designed to announce his or her forefather's caste and place of origin. (455)

Although Mukherjee's upbringing and experiences contrast with Jasmine's in many ways, it is worth noting how her attitude towards Independence makes its way into the novel. Mukherjee, having been born into a comfortably 
colonized socio-economic situation, is expected and ultimately unable to adapt to a previous, imagined, and idealized pre-colonial India. Jasmine, who is born into a socio-economic position rendered quite uncomfortable by Independence (and particularly by the consequences of Partition), is raised in the shadow of this undivided and colonial India:

The issue is not that such stereotypical Jyotis are nowhere to be found, but That the exaggerated stereotyping begins by constructing but not holding On to a farcical image of oppressed Indian womanhood - an image which Might have a special appeal for western liberal feminism, which looks for Exactly such images of oppressed sisters in need of rescue. (76)

But there is a difference between translating India as oppressive, as Cushy and Anaya believe Mukherjee does in Jasmine, and expressing ambivalence towards the political and social instability that remains after Independence.

\section{Conclusion}

As the protagonists perceive both their race and sexuality through new and different lenses throughout the course of the text, they come to realize that the notion of a singular identity is a fallacy and the reality of the diasporic experience is the indeterminate multiplicity. This multiplicity becomes a significant plight of the characters, for as their different consciousnesses contradict each other, the characters are left uncertain as to the nature of their identities, not knowing where they fit in the

Mukherjee's characters with different socio-cultural experiences relate to a process involving complex negotiation and exchange. Mukherjee always has a concern that the new identity should not suffer from marginalization and suppression from any society. To avoid such circ 7 mstances she portrays her characters with qualities like individualism, independence, courage and decisiveness. Duality and conflict is not merely a feature of immigrant life in American. Mukherjee's women are bought up in a culture which ingrains them into such mindset even from childhood. Breaking of linguistic and cultural barrier begins early, due to the British colonization.

\section{References:}

1. Mukherjee, Bharathi. Jasmine. New York: Gross press, 1989. Print.

2. Bose, Brinda. "A Question of identity: Where Gender, Raceand America Meet in Bharati

3. Mukherjee." Critical Perspectives. Emmanuel S. Nelson. New York \& London: Garland Publishing Inc., 1993. 47-63. Print.

4. Carabs, Thomas J. "Tristes Tropisms: Bharathi Mukherjee's Sidelong Glances at America." The literary Half-Yearly 35.1(Jan 1994): 51-63. Print.

5. Chowdhury, Enakshi. "Images of Woman in Bharathi Mukherjee's Novel." LiteraryVoice 2 (Oct 1995): 8187. Print.

6. Dhaliwal, Amarpal K., "Other Subjects: identity, Immigration, Representations of Difference in Jasmine." South Asian Review 18.15(Dec 1994): 15-25. Print.

7. Gomez, Christine, "The On-Going Quest of Bharati Mukherjee from Expatriation to Immigration." Indian Women Novelist: Set II: Vol.3.R.K. Dhawan. New Delhi: $\quad$ Prestige Books, 1995. 71-87. Print.

8. Grewal, Gurleen, "Born Again American: The Immigrant Consciousness in Jasmine." Bharati Mukherjee: Critical Perspectives. Emmanuel S. Nelson. New York \& London: Garland Publishing Inc., 1993. 181-196. Print.

9. Indira, S. "Jasmine: An Odyssey of Unhousement and Enhousement." Commonwealth writing: A Study in Expatriate Experience. R.K. and L.S.R. Krishna sastry Dhwan. New Delhi: Prestige Books, 1994. 86-90. Print.

10. Joseph, Eliza. "Perspectives on the Mestiza Consciousness: Bharati Mukherjee's Desirable Daughters." Indian Journal of Postcolonial Literature 9.1 (June2009): 91-99. Print.

11. Lahiri, Sharmita. "Where Do I Come From? Where Do I Belong? Identity and Alienation in Bharati, Mukherjee's Desirable Daughters and Jhumpa Lahiri's The Namesake." South Asian Review 31.1 (Novemeber 2010): 118-140. Print.

12. Nityanadam, Indira. "Yasmine Gooneratne's A change of Skies and Bharati Mukherjee's Jasmine: The Immigrant Experience in Australia and the U.S.A." Commonwealth Writing: A Study in Expatriate Experience. R.K. and L.S.R. Krishna Sastry Dhwan. New Delhi: Prestige Books, 1994. 50-54. Print. 
13. Padma, T., "From Acculturation to Self-Actualization: Diaspora Dream in Bharati Mukherjee's Jasmine." Commonwealth Writing: Study in Expatriate Experience. R.K. and L.S.R. Krishna sastry Dhwan. New Delhi: Prestige Books, 1994. 77-85.Print.

14. Padimi, P., "Bharati Mukherjee's Jasmine: A Celebration of the Strength of Woman." Indian Research Journal of Literature in English 1.1 (Jan-June 2009): 60-67. Print.

15. Sivaraman, S., "Jasmine: A Search of Alternate Realities." Recent Indian fiction. Ed. R.S.Pathak. New Delhi: Prestige Books. 210-218. Print. 